\title{
Investigation of Pozzolanic Activity Indexes of Pasinler Obsidian and Zinc Slag
}

\author{
Metehan ARDAHANLI ${ }^{1 *}$, Meral OLTULU ${ }^{2}$
}

\begin{abstract}
Pozzolanes are mineral additives that have been widely used in concrete production recently. The main purposes of pozzolana additives used in concrete are to provide economy and improve various properties of concrete. In this study, obsidian mineral which located in Pasinler District of Erzurum Province and has high amount of reserves in the world with high silica content, and zinc slag which occurring during the production of zinc metal, in the metal industry mainly in Turkey and high production capacity in the world, pozzolanic properties has been investigated. For the pozzolanic activity test, mortar samples were produced by using 5, 10, 15, 20 and 25\% obsidian; 2.5, 5, 7.5 and $10 \%$ zinc slag instead of cement. Samples produced for the determination of pozzolanic activity index were kept at 7 and 28 -days standard cure. At the end of the curing period, pozzolanic activity indexes were determined on the basis of compressive strength. As a result of the pozzolanic activity test, the highest pozzolanic activity value was obtained at the rate of $15 \%$ for obsidian and 5\% for zinc slag. When the results are examined, it is determined that both materials can be used as pozzolan instead of cement.
\end{abstract}

Keywords: Obsidian, Zing slag, Pozzolanic activity index, Compressive strength.

\section{Pasinler Obsidiyeni ve Çinko Cürufunun Puzolanik Aktivite İndekslerinin İncelenmesi}

\section{Öz}

Puzolanlar son zamanlarda beton üretiminde yaygın bir şekilde kullanılan mineral katkı maddeleridir. Betonda kullanılan puzolan katkılarının temel amaçları; ekonomiklik sağlamak ve betonun çeşitli özelliklerini iyileştirmektir. Bu çalışmada yüksek silis içerikli dünyada yüksek miktarda rezervi olan ve Erzurum İli Pasinler İlçesi’nde de bulunan obsidiyen minerali ile metal endüstrisinde başta Türkiye olmak üzere tüm dünyada üretim kapasitesinin yüksek olduğu çinko metalinin üretimi sırasında meydana gelen çinko cürufunun, puzolanik özellikleri incelenmiştir. Puzolanik aktivite deneyi için çimento yerine $\% 5,10,15,20$ ve 25 oranlarında obsidiyen; $\% 2.5,5,7.5$ ve 10 oranlarında çinko cürufu kullanılarak harç numuneler üretilmiştir. Puzolanik aktivite indeksinin belirlenmesi için üretilen numuneler 7 ve 28 gün standart kürde tutulmuştur. Kür süresi sonunda basınç dayanımını esasına göre puzolanik aktivite indeksleri belirlenmiştir. Puzolanik aktivite deneyi sonucunda en yüksek puzolanik aktivite değeri obsidiyen için $\% 15$ ve çinko cürufu için $\% 5$ oranında elde edilmiştir. Sonuçlar incelendiğinde her iki malzemeninde çimento yerine puzolan olarak kullanılabileceği belirlenmiştir.

Anahtar Kelimeler: Obsidiyen, Çinko cürufu, Puzolanik aktivite indeksi, Basınç dayanımı.

\footnotetext{
${ }^{1}$ Erzurum Tecnical University, Civil Engineering Department and Faculty of Engineering and Architecture, Erzurum, Turkey, metehan.ardahanli@erzurum.edu.tr

${ }^{2}$ Atatürk University, Civil Engineering Department and Faculty of Engineering Erzurum, Turkey, mroltulu@atauni.edu.tr
}

${ }^{1}$ https://orcid.org/0000-0002-8091-2792 $\quad{ }^{2}$ https://orcid.org/0000-0002-3779-6888 


\section{Introduction}

Pozzolanes are divided into 2 main parts; natural pozzolans; volcanic ash, tuff, diatomaceous earth and similar materials containing the residues of siliceous algae called diatoms, and some clays that have been fired up to a certain temperature are included in this class. Artificial pozzolanes that emerge as a by-product during industrial production such as fly ash, granulated blast furnace slag and silica fume, rice husk ash (Erdoğan and Erdoğan, 2007). Artificial pozzolans such as fly ash, silica fume and blast furnace slag, which take up space in nature as waste products, are widely used in concrete production (Ardahanlı et al., 2021; Bascetin et al., 2021; Alameri et al., 2020; Bascetin et al., 2020; Ardahanlı et al., 2019; Alameri et al., 2019; Şahin et al., 2019; Wang et al., 2017; Nowak, 2014; Wong and Razak, 2005; Siddique, 2004).

Pozzolanes; improve workability, mechanical properties and various durability properties, reduce the heat of hydration, and reduce the cost. In addition, they can increase the water requirement, reduce the hardening and strength gain velocity. In general, the materials that are classified as natural and artificial pozzolan and the materials that are specified in their definition $\left(\mathrm{SiO}_{2}, \mathrm{Al}_{2} \mathrm{O}_{3}\right)$ are carried out in studies to determine whether they show pozzolanic properties.

When portland pozzolanic cements obtained by pozzolanes added to Portland cement come into contact with water, the portland cement begins to hydration reaction and calcium silicates form calcium silica hydrate gels that provide strength in the cement and calcium hydroxide as a byproduct. The pozzolanic mineral additive reacts with calcium hydroxide, the hydration product of Portland cement, to form calcium silica hydrate gels, which are the main component of strength (Erdoğan and Erdoğan, 2007). Thus, pozzolans can affect strength early or in the long term, depending on the silica content they contain (Ardahanl1 et al., 2021; Bascetin et al., 2021; Wang et al., 2017; Nowak, 2014; Tohumcu et al., 2013).

Pozzolanic activity index concept used for pozzolan; it is the ratio of the compressive strength of the mortar sample produced by substituting pozzolan in certain proportions in accordance with the standards to the compressive strength of the mortar without pozzolan. The pozzolanic activity index can be compared with the type and ratio of pozzolan. When the standards of the commonly used pozzolan are examined; according to TS EN 450-1 (2013) standard, in order for fly ash to be used as pozzolan, 28-day pozzolanic activity index should be minimum 75\%, 90-day pozzolanic activity index should be at least 85\%, whereas according to TS EN 15167-1 (2006)standard for the blast furnace slag to be used as a pozzolan, a 7 -day pozzolanic activity index should be a minimum of $45 \%$ and a 28-day pozzolanic activity index should be a minimum of $70 \%$.

The materials used as pozzolan can be volcanic natural pozzolan and artificial pozzolan (Mouli and Khelafi, 2008; Moropoulou et al., 2004). Obsidian stone is a natural volcanic origin stone 
containing high silica with a translucent structural appearance and glassy luster. In Turkey Rize İkizdere region pozzolanic using 25\% obsidian instead of cement activity index 7-day \% 77.4828 day \% 90.41, and the 90-day \% 95.68 is (Kaya and Ustabaş1, 2019) 40\% obsidian from this region comparing the compressive strength of mortars obtained by using mortars instead of cement and using blast furnace slag and fly ash at the same rate, after 28-days of curing, it was determined that obsidian increased its strength more than fly ash (Ustabaş and Ömür, 2019).

The carbon dioxide and carbon monoxide gases mixed into the nature during the emergence of zinc slags, whose silica ratio is close to the ratio of cement, can adversely affect both our health and air . Also recovery provided can not be increased once the storage costs of zinc slag, the store emerged as an additional expense to the factory where the production (landfill) costs at the per tonne of 7-10 USA dollars (USD) finding, if the adequate storage of non-factory plant that cost up to 20 USD When considered as hazardous wastes while rising, this cost increases by approximately 140 USD per ton and reaches up to 100-150 USD (Bakar, 2005). For this reason, it is of special importance to remove metallic slags from nature. Öztürk et al., (2018) concluded that the concretes obtained by using zinc slag instead of aggregate in different proportions are lightweight concrete samples that are equivalent to the standard concrete after 28-days of curing, Aslan et al., (2019) it was determined that the best compressive strengths of $10 \%$ were obtained at the end of the standard curing for 7, 14 and 28-days in the mortar samples by using zinc slag at 10\%,20\% and $30 \%$ instead of cement.

While there are many different studies on artificial pozzolan in the literature, studies on obsidian and zinc slag are very limited. In this study, it was aimed to investigate the pozzolanic properties of the waste material, zinc slag, and the natural rock, obsidian, as well as to provide economy as these materials can be used as cement substitutes in concrete and to reduce the environmental pollution caused by zinc slag.

\section{Materials and Methods}

\subsection{Material}

In the study, CEM I 42.5 R type cement in accordance with TS EN 197-1 (2012) standard obtained from Erzurum Aşkale Cement Factory was used and the chemical properties of this cement type, Pasinler obsidian and zinc slag are given in Table 1. 
Table. 1. Chemical properties of CEM I 42,5 R type cement, obsidian and zing slag.

\begin{tabular}{llll}
\hline Content $(\%)$ & Cement & Obsidian & Zing Slag \\
\hline $\mathrm{SiO}_{2}$ & 18.10 & 77.3 & 16.10 \\
$\mathrm{Al}_{2} \mathrm{O}_{3}$ & 4.48 & 12.9 & 8.53 \\
$\mathrm{Fe}_{2} \mathrm{O}_{3}$ & 3.09 & 1.08 & 26.47 \\
$\mathrm{CaO}$ & 63.65 & 0.32 & 29.83 \\
$\mathrm{MgO}$ & 2.58 & 0.04 & 3.22 \\
$\mathrm{SO}_{3}$ & 2.84 & - & - \\
$\mathrm{Loss}_{\mathrm{N}}$ of İnition & 3.9 & - & 11.10 \\
$\mathrm{Na}_{2} \mathrm{O}$ & 0.21 & 3.94 & - \\
$\mathrm{K}_{2} \mathrm{O}$ & 0.62 & 4.30 & - \\
$\mathrm{Na}_{2} \mathrm{O}+0.66 \mathrm{~K}_{2} \mathrm{O}$ & 0.62 & - & - \\
$\mathrm{Cl}$ & 0.015 & - & - \\
$\mathrm{Immeasurable}$ & 0.52 & - & - \\
$\mathrm{Total}$ & 100 & - & - \\
Free CaO & 0.44 & - & - \\
Unsolvable Residue & 0.55 & - & - \\
\hline
\end{tabular}

Standard CEN sand (Figure 1) was used in the mortar samples produced and obsidian stones were obtained from Pasinler District (Figure 2). Zinc slag Kayseri Çinkom A.Ş provided from the company.

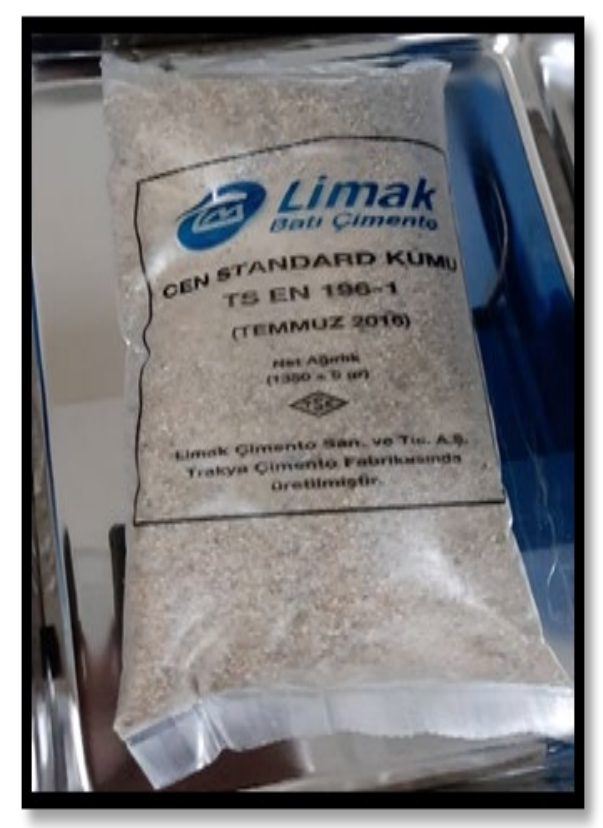

Figure 1. CEN standard sand. 


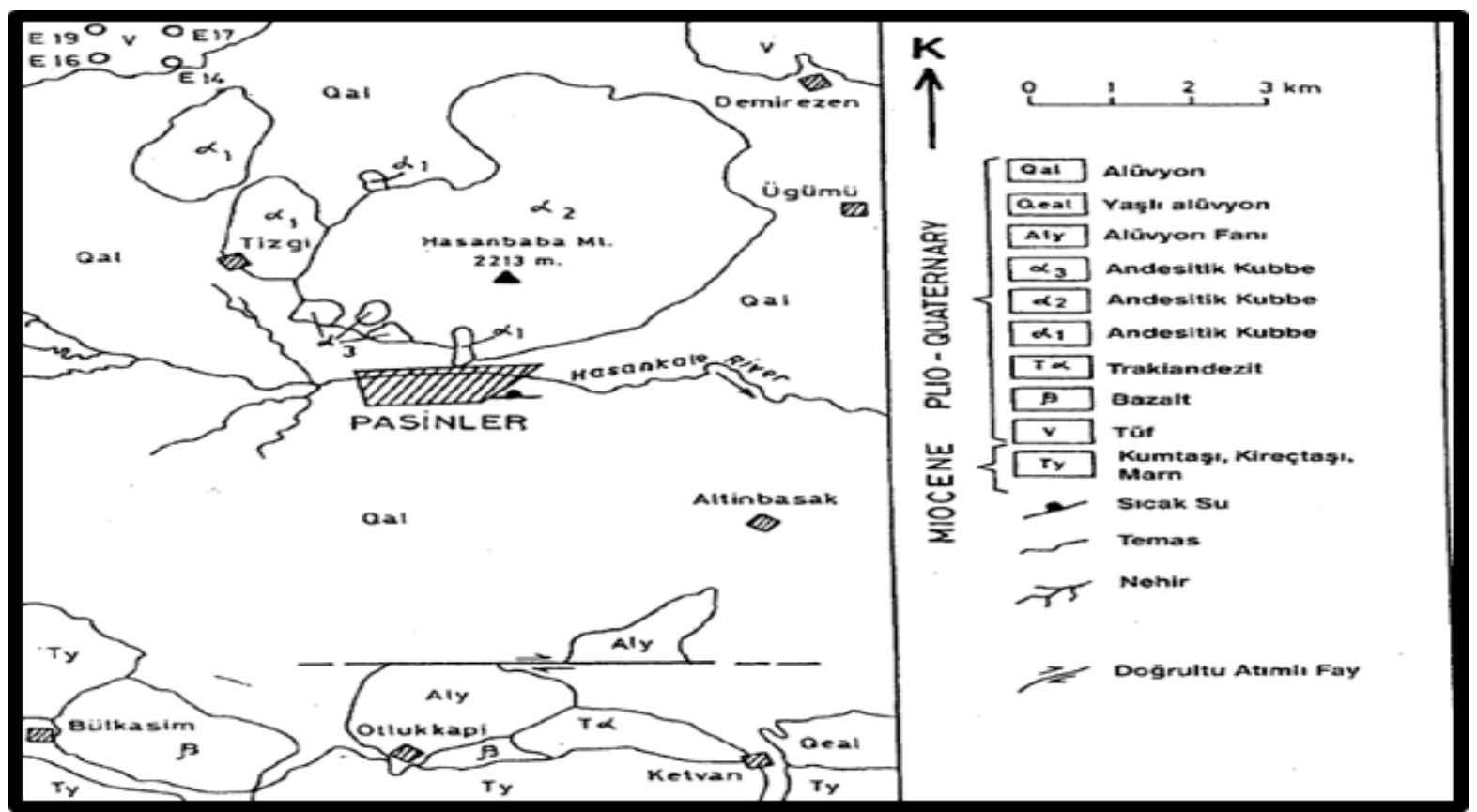

Figure 2. Obsidian map of Pasinler County (Bigazzi et al., 1997).

Main countries that extract Obsidian from the ground: Mexico, Scotland, America, Italy, Greece, Armenia and Turkey. In the reserve calculations made in relation to obsidians in Turkey, the amount of obsidian of 5.850.000 tons was revealed (Bilgin et al., 2012).

In Turkey, obsidian deposits in Eastern Anatolia Nemrut, Suphan, Tendurek and around Mount Ararat; it is found in different types and sizes around large young mountains such as Erciyes and Hasan Mountain in the Central Anatolia Region. In addition to these deposits, obsidian deposits were found around Rize, Bingöl, Erzurum, Erzincan, and between Ankara and Bolu (Ercan et al., 1990).

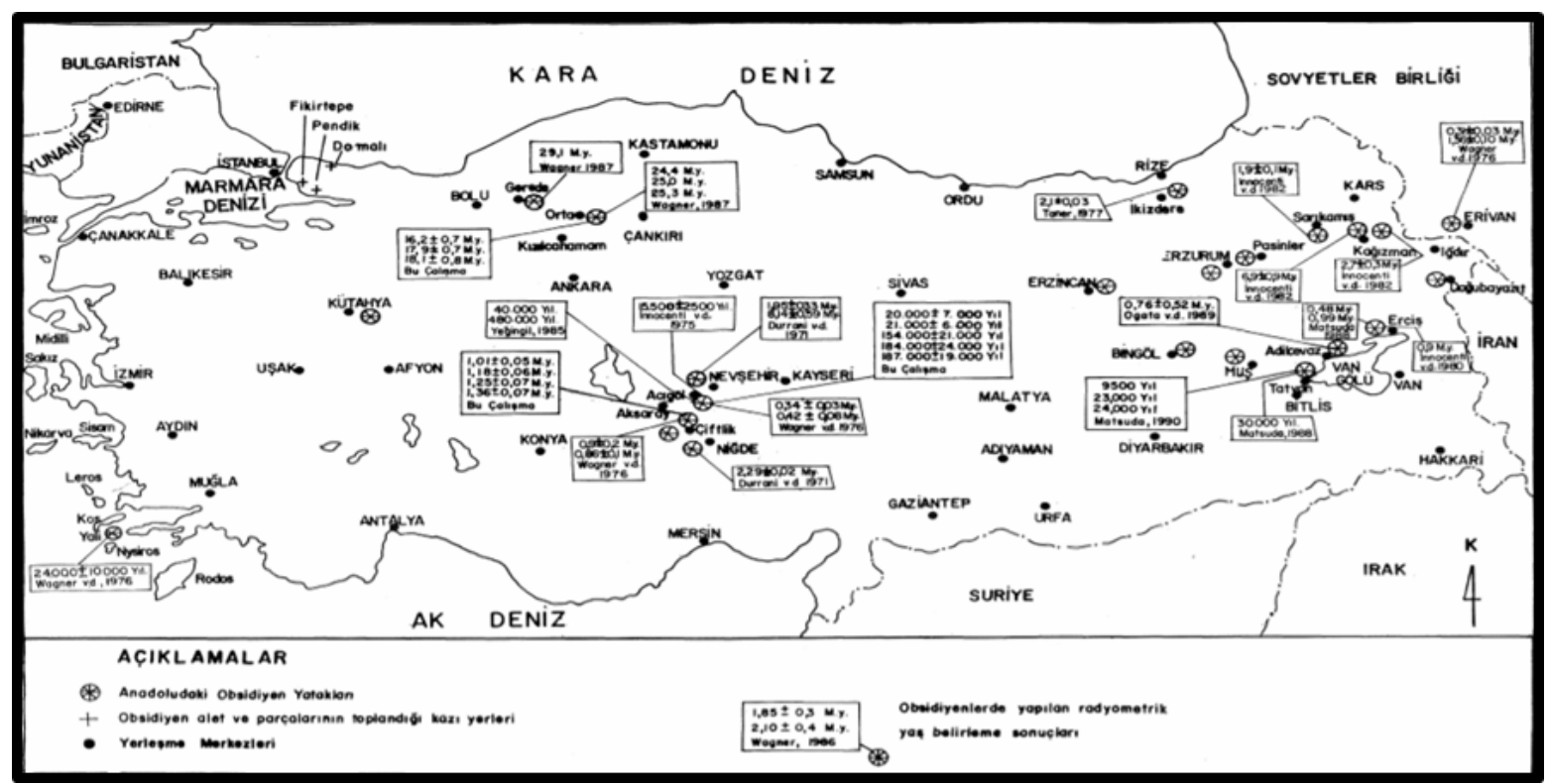

Figure 3. Obsidian deposit in Turkey (Ercan et al., 1990). 
Turkey's geographic region having the largest area is taken into consideration when volcanic topography maps of Eastern Anatolia. This region is very rich in terms of obsidian presence as seen on the map in Figure 2 (Akköprü et al., 2017).

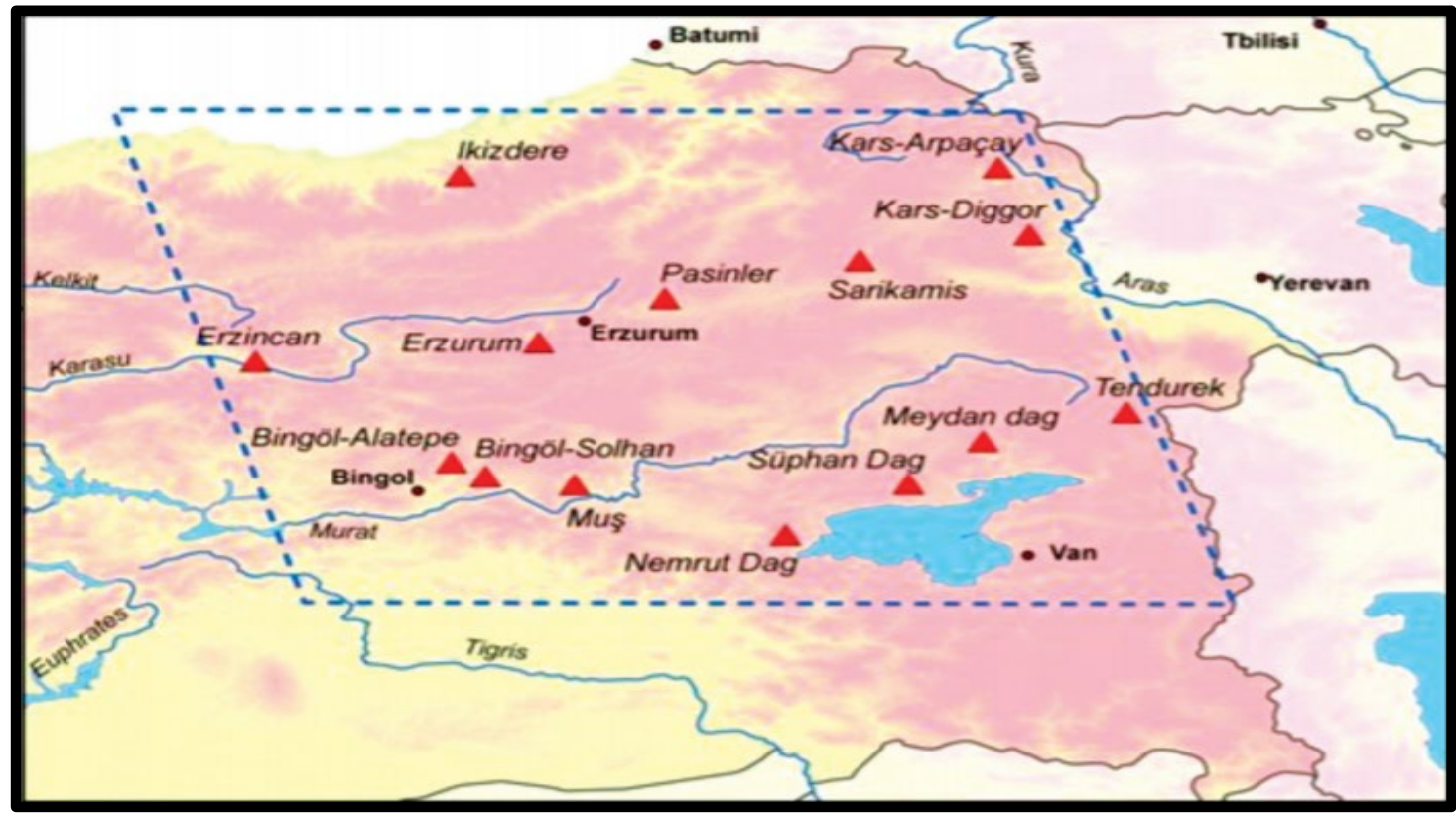

Figure 4. Eastern Anatolia Region obsidian resources (Akköprü et al., 2017).

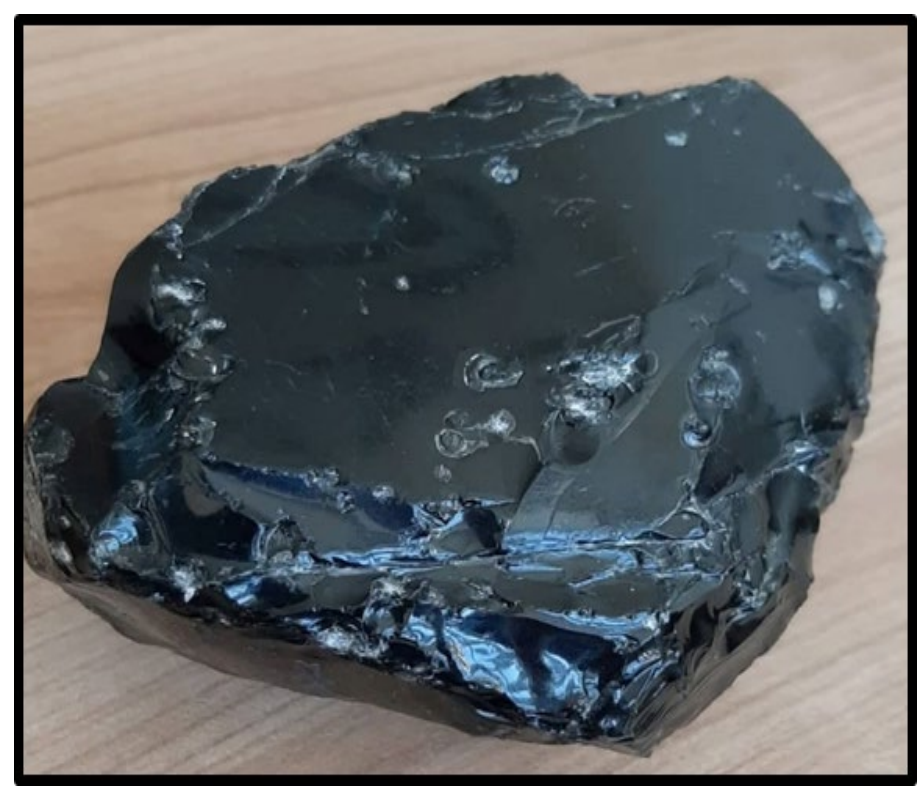

Figure 5. Pasinler obsidian.

After the Pasinler Obsidian was collected in natural environment, it was reduced to a micron size with the help of a crusher and a Los Angeles device. 


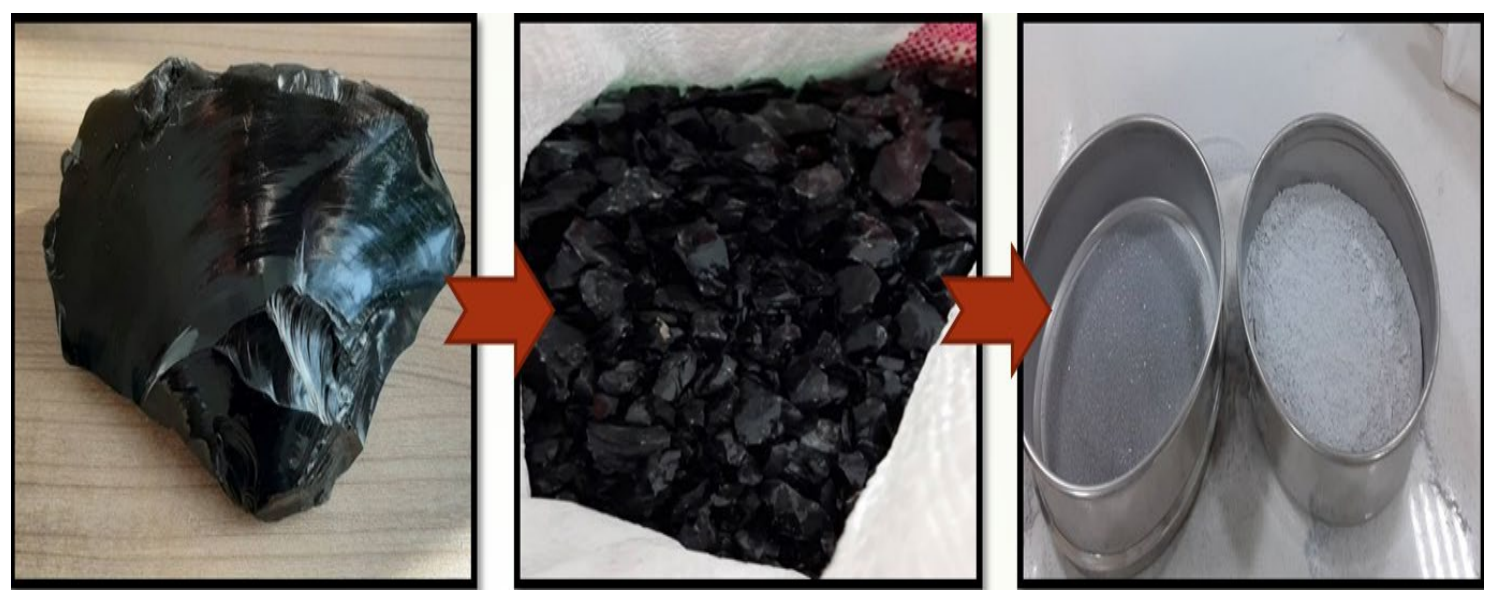

Figure 6. Stages of obsidian preparation for the experiment.

About 200 million tons of zinc metal was found in the world, this amount is about 2.3 million tons of reserves in Turkey. USA, Canada, Australia, China are the countries with the most zinc reserves in the world. The production made from these zinc ore reserves is 8 million tons in the world, and the amount of waste material zinc slag obtained as a result of the production is 0.5 million tons. Zinc metal consumption in our country is remarkably level is 60 thousand tons (Union of Turkish Engineers and Architects Chamber of Geological Engineers, 2021).

Turkey mostly extracted zinc and lead mine in the eastern Black Sea region, in central Anatolia and Kayseri surrounding provinces are seen as intense. It is seen that the Eastern Black Sea in Turkey map shown in Figure 7 and in addition the Marmara region of western central Anatolia, to have the zinc-lead mine deposit.

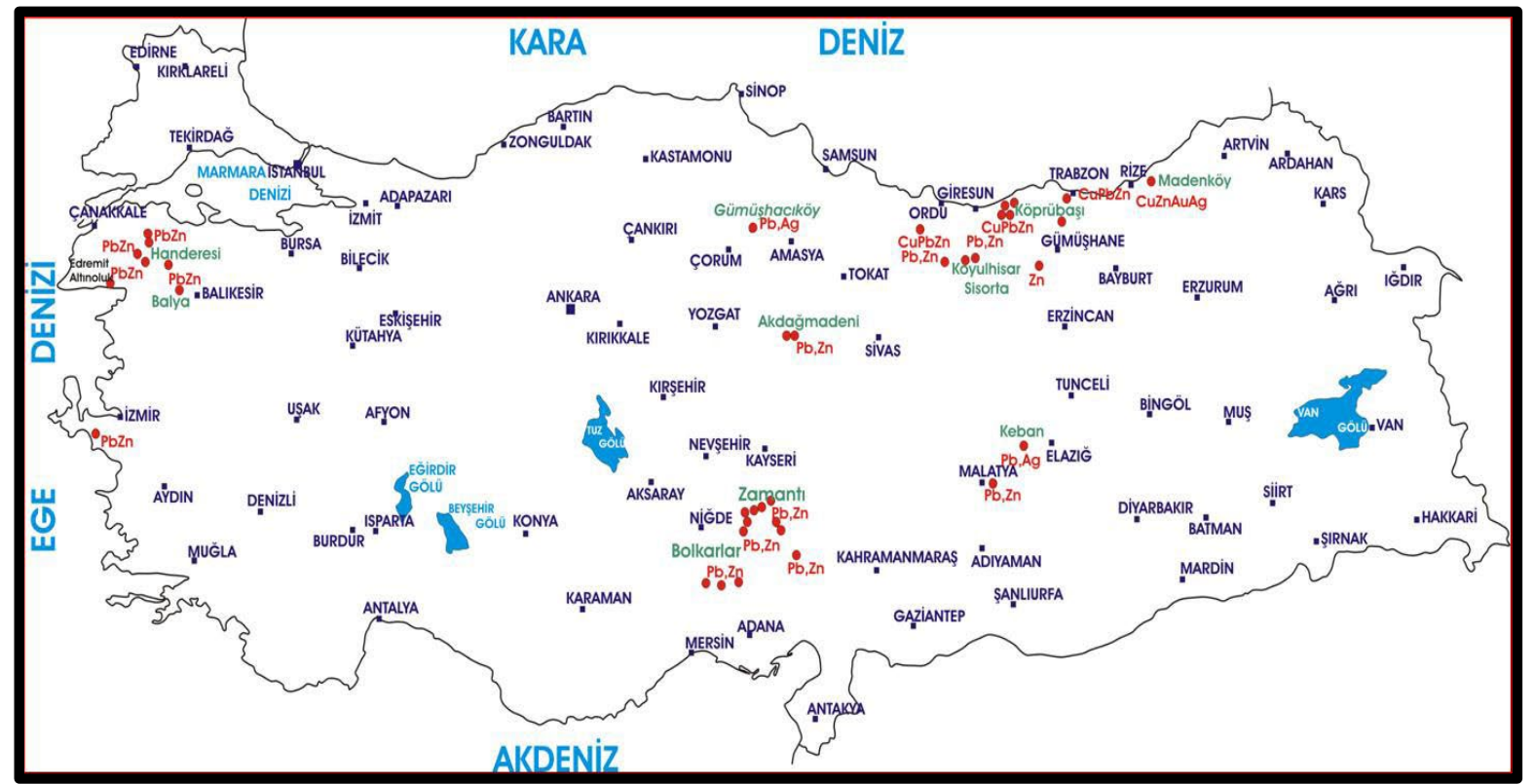

Figure 7. Lead and zinc deposits in turkey (Union of turkish engineers and architects chamber of geological engineers, 2021). 


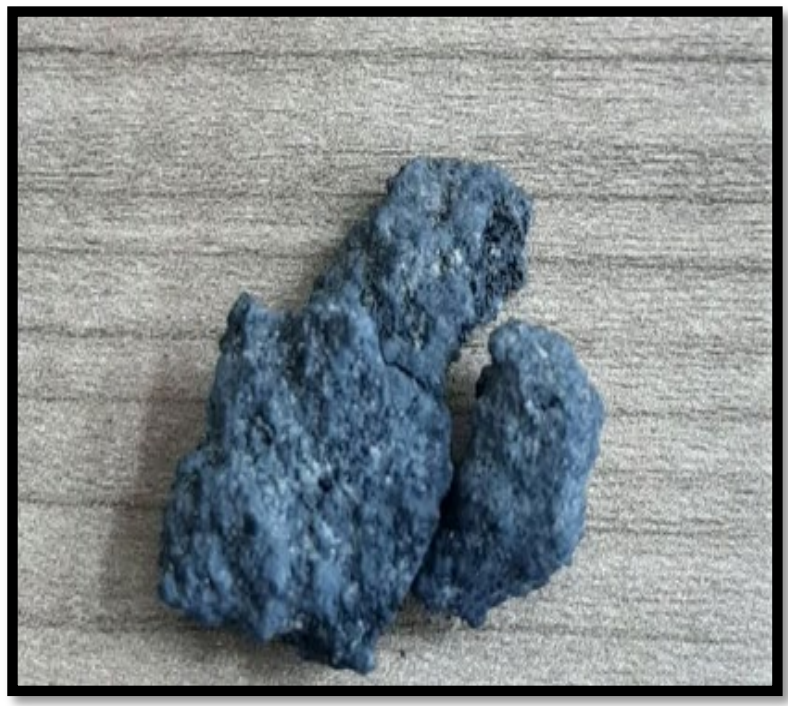

Figure 8. Zinc slag.

\section{Mixing Groups}

The mortar mix groups prepared for the pozzolanic activity test are given in Table 2. In this table, the mixing ratios of the materials by weight and their mixing codes are shown.

Table 2. Mortar groups.

\begin{tabular}{lllll}
\hline Mortar Groups & Cement & Sand & Substitution Ratio & Water \\
\hline C & 1 & 3 & - & 0.5 \\
OP5 & 0.95 & 3 & 0.05 & 0.5 \\
OP10 & 0.90 & 3 & 0.10 & 0.5 \\
OP15 & 0.85 & 3 & 0.15 & 0.5 \\
OP20 & 0.80 & 3 & 0.20 & 0.5 \\
OP25 & 0.75 & 3 & 0.25 & 0.5 \\
ZS2.5 & 0.975 & 3 & 0.0025 & 0.5 \\
ZS5 & 0.95 & 3 & 0.05 & 0.5 \\
ZS7.5 & 0.925 & 3 & 0.075 & 0.5 \\
ZS10 & 0.90 & 3 & 0.10 & 0.5 \\
\hline
\end{tabular}

OP: Obsidian powder, ZS: Zinc slag, C: Reference sample.

\subsection{Method}

\section{Pozzolanic Activity Index}

From each of the specified groups (Table 2), 3 pieces of $5 \times 5 \times 5 \mathrm{~cm}$ detached cubic mortar samples were produced. After these samples were kept for 7 and 28-days in the standard cure, the pozzolanic activity index was determined based on the compressive strength according to the TS EN 196-5 (2012) standard.

Pozzolanic Activity Index $(\mathrm{PAI})=\frac{\text { Average Compressive Strength of Pozzolan Mortar Samples }}{\text { Average Compressive Strength of Control Mortar Samples }}$ 

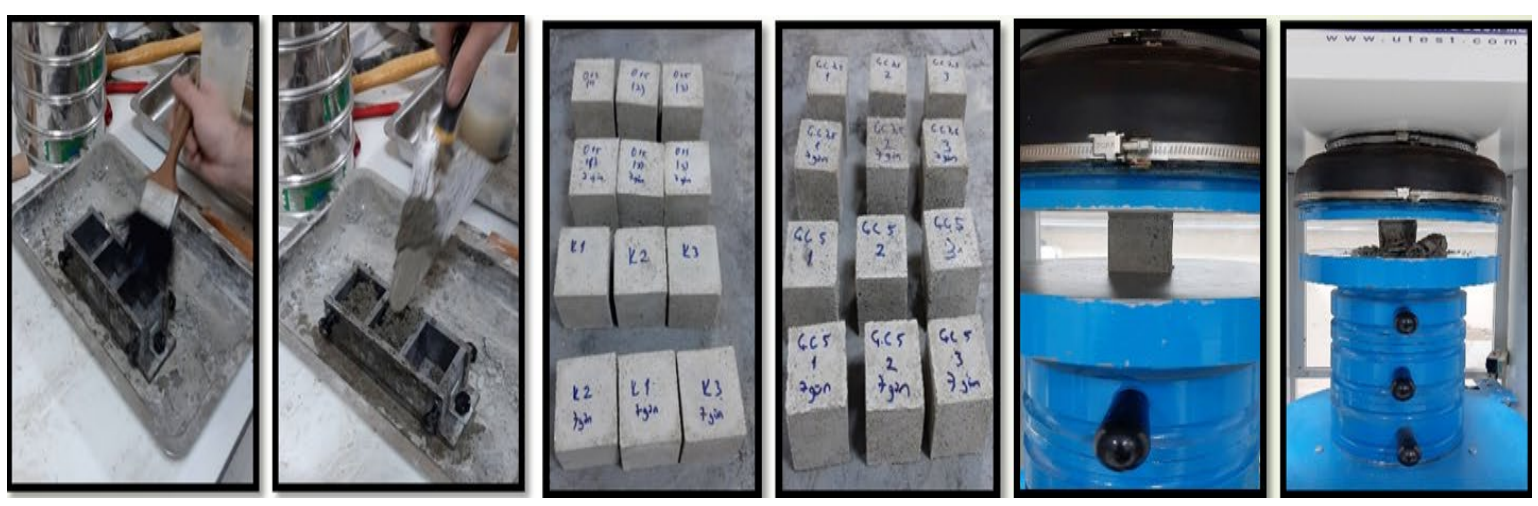

Figure 9. Pozzolanic activity test.

\section{Findings and Discussion}

$\mathrm{SiO}_{2}$, which is found in pozzolanic materials used in pozzolanic reactions in cement or concrete, reacts with $\mathrm{Ca}(\mathrm{OH})_{2}$ formed as a result of hydration of the cement with water and creates C-S-H gels, resulting in an increase in strength in the short or long term (Erdoğan and Erdoğan, 2007). When Table 1 is evaluated, it is seen that the silica amount of Pasinler obsidian is much higher than the amount of silica and the silica amount of zinc slag. According to TS EN 196-2 (2013) standard silica content in the blast furnace slag and fly ash used as pozzolan approximately $40 \%$ to $50 \%$. While silica ratio of the Pasinler obsidian is high enough compared to the ratio of these two artificial pozzolan, the silica ratio of the zinc slag is partially low.

For this experiment, $50 \times 50 \times 50 \mathrm{~mm}$ sized samples were produced and 3 samples from each group were tested in accordance with the TS EN 196-5 (2012) standard. The compressive strengths of the samples produced in two different curing periods (7 day and 28-day) were measured and in Table 3, the average compressive strength and pozzolanic activity index of the mortar samples remaining in the water curing for 7 and 28-days are given.

Table 3. Pozzolanic activities of mortar groups.

\begin{tabular}{|c|c|c|c|c|}
\hline \multirow[t]{2}{*}{ Mortar Groups } & \multicolumn{2}{|c|}{$\begin{array}{l}\text { Average } \\
\text { Compressive Strength }(\mathrm{MPa})\end{array}$} & \multicolumn{2}{|l|}{$\begin{array}{l}\text { PAI } \\
(\%)\end{array}$} \\
\hline & 7 Day & 28 Day & 7 Day & 28 Day \\
\hline $\mathrm{C}$ & 52.82 & 68.96 & - & - \\
\hline OP5 & 34.50 & 48.13 & $\% 66$ & $\% 70$ \\
\hline OP10 & 39.76 & 54.89 & $\% 76$ & $\% 80$ \\
\hline OP15 & 42.33 & 57.31 & $\% 80$ & $\% 83$ \\
\hline OP20 & 37.25 & 47.46 & $\% 71$ & $\% 69$ \\
\hline OP25 & 35.41 & 46.42 & $\% 67$ & $\% 68$ \\
\hline ZS2.5 & 34.99 & 48.01 & $\% 67$ & $\% 70$ \\
\hline ZS5 & 38.32 & 48.59 & $\% 73$ & $\% 71$ \\
\hline ZS7.5 & 31.56 & 47.06 & $\% 60$ & $\% 69$ \\
\hline ZS10 & 27.92 & 38.93 & $\% 53$ & $\% 57$ \\
\hline
\end{tabular}


In Figure 10, the graph showing the 7-day pozzolanic activity indexes determined on the basis of compressive strength of the mortars formed by substituting obsidian powder at $5 \%, 10 \%, 15 \%$, $20 \%$ and $25 \%$ instead of cement is given. When the literature is examined, since it is seen that the peak pozzolanic value of obsidian material is obtained by using $25 \%$ instead of cement and it is seen that the pozzolanic activity decreases depending on the increase in the ratio (Kaya and Ustabaşı, 2019; Ustabaş and Ömür, 2019 ), substitution at this rate and below was used in this study.

As can be seen in this figure, the highest pozzolanic activity of the 7-day mortar samples was obtained in OP15 with $80 \%$. While the rate of substitution of obsidian powder instead of cement in 7 -day samples increased in direct proportion to the pozzolanic activity index up to $15 \%$, it was determined that the pozzolanic activity index decreased due to the increase of obsidian dust from the OP15 mortar group, where it reached the maximum value, which was used as a $15 \%$ replacement. According to the TS EN 15167-1 (2006) standard, the 7-day pozzolanic activity index must be 45\% in order to be used as a pozzolan in blast furnace slag. The lowest pozzolanic activity index of the samples created using obsidian powder is at OP5 with $66 \%$, and compared to the standard of blast furnace slag pozzolan, it is $21 \%$ on the safe side. As can be seen in Figure 10, depending on the increase in the ratio of obsidian powder in cement, the pozzolanic activity index increased by $10 \%$ in OP10 compared to OP5 and 4\% in OP15 compared to OP10; in OP20, there was a 9\% decrease compared to OP15, and a decrease of 13\% compared to OP15 if it was OP25. The highest pozzolanic activity index difference was determined to be $10 \%$ between OP10 and OP5.

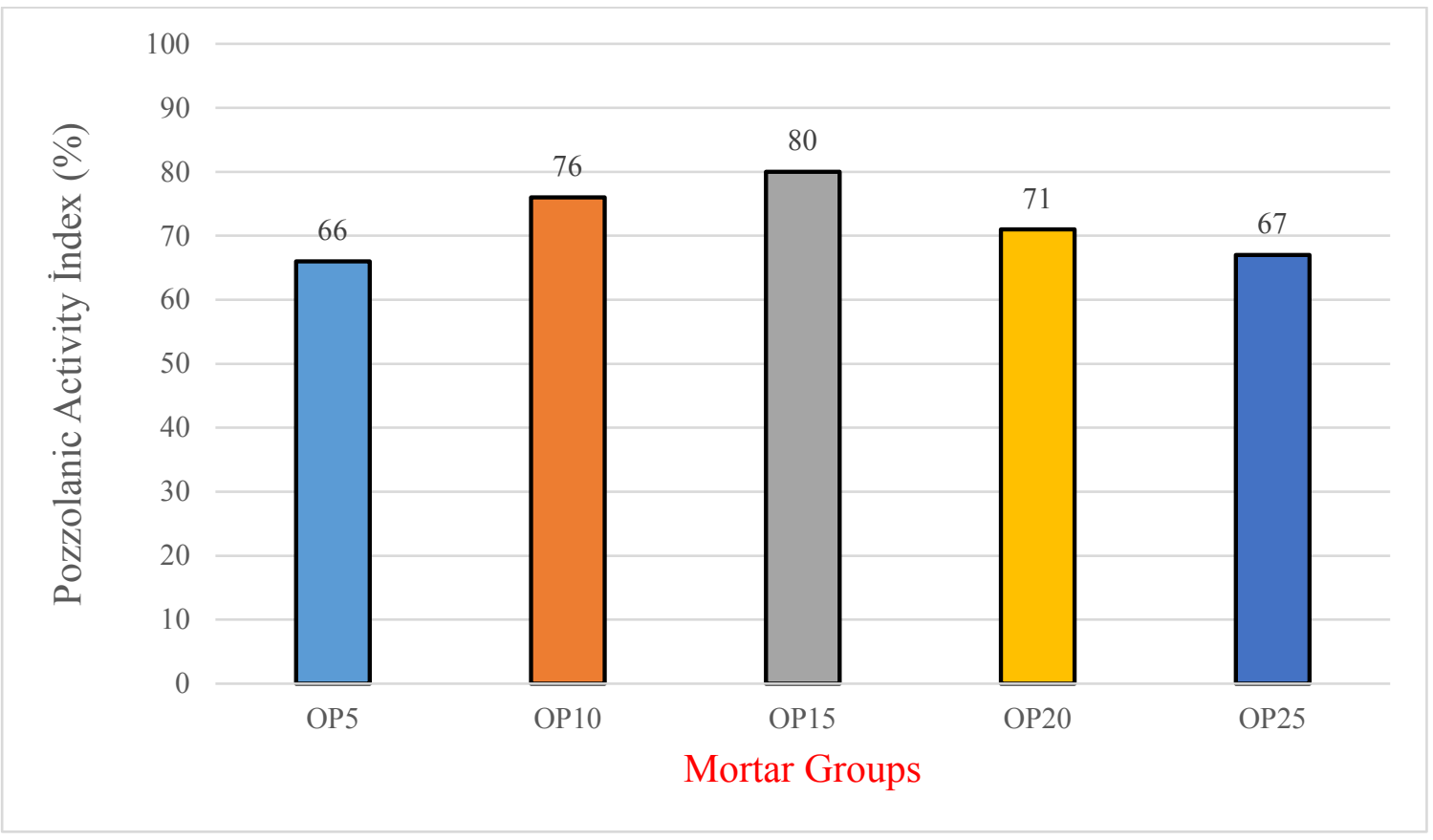

Figure 10. 7-Day pozzolanic activity index of obsidian powdered samples. 
Figure 11 shows the pozzolanic activity indexes determined according to the strength of the mortar samples formed by replacing obsidian powder with $5 \%, 10 \%, 15 \%, 20 \%$ and $25 \%$ instead of cement at the end of 28-days curing. As can be seen in the figure, the highest pozzolanic activity index in the mortars with obsidian powder for 28 days was obtained in the OP15 mortar group, while an increase in the pozzolanic activity index was observed due to the increase in the amount of obsidian up to $15 \%$ substitution ratio, and a decrease in the pozzolanic activity index with the increase in the amount of obsidian from the substitution rate of 15\% was determined. The main reason for this situation is that the pozzolanic material added instead of cement reduces the amount of cementderived $\mathrm{CH}$ and cannot meet the increasing pozzolanic amount of $\mathrm{SiO}_{2}$ mineral. Therefore, losses in strength may occur after a rate that can be determined experimentally. According to TS EN 450-1 (2013) in order for fly ash to be used as pozzolan in cement, 28 days pozzolanic activity index is minimum 75\% and according to TS EN 15167-1 (2006), in order for blast furnace slag to be used as pozzolan in cement, 28 days pozzolanic activity index should be at least $70 \%$. When the pozzolanic activity indexes of the samples produced using obsidian powder were examined after 28 days of curing, $83 \%$ pozzolanic activity value was obtained in the OP15 mortar group and it was seen that obsidian belonging to Erzurum Pasinler District could be used as a pozzolanic substitute for cement.

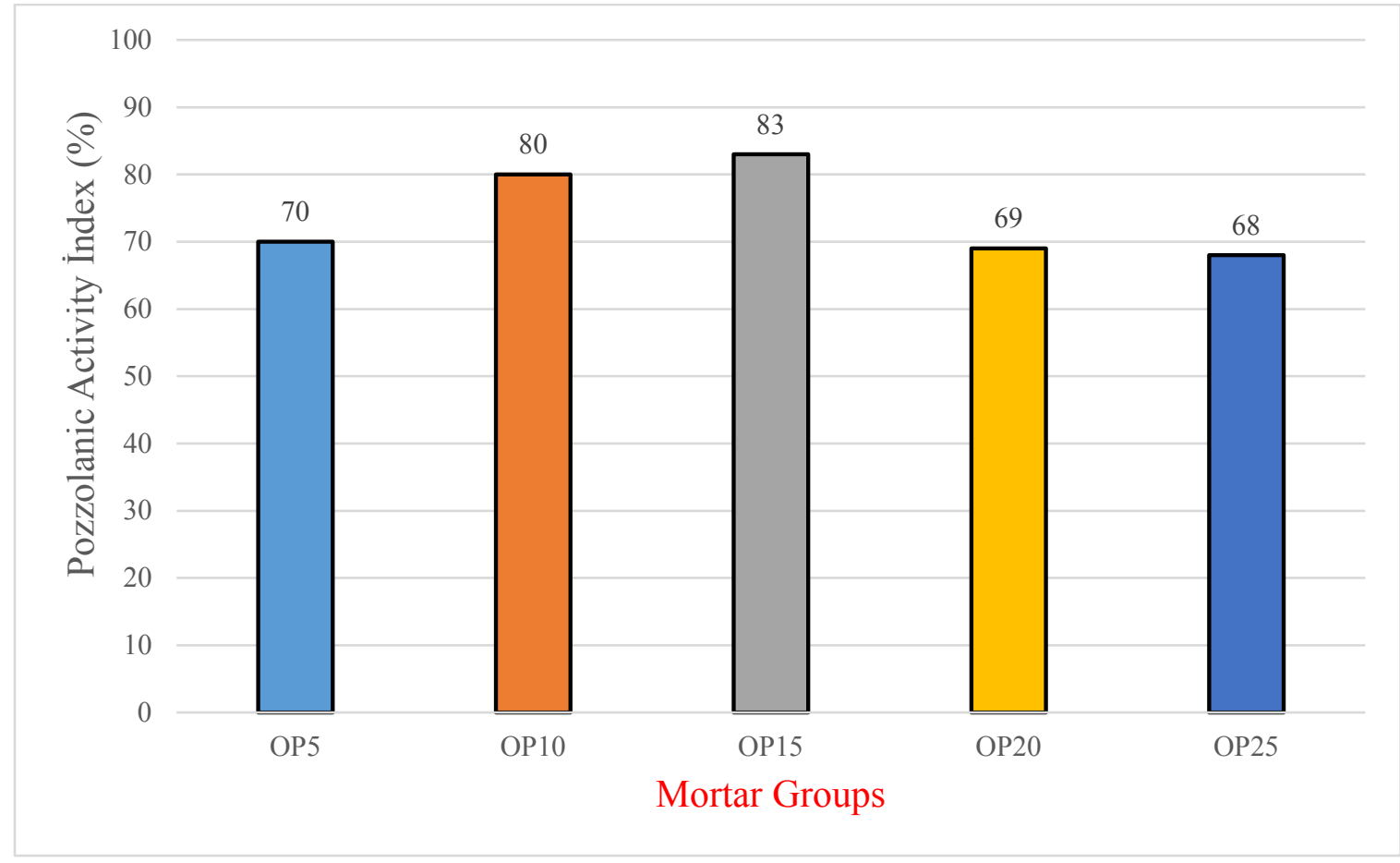

Figure 11. 28-Day pozzolanic activity index of obsidian powdered samples.

In Figure 12, the results of the pozzolanic activity indexes of the mortar samples produced by substituting $2.5 \%, 5 \%, 7.5 \%$ and $10 \%$ of the zinc slag instead of cement are given in accordance with the compressive strength at the end of the 7-day standard water cure. When the literature is examined, since it is seen that the peak pozzolanic value of zinc slag is obtained by using $10 \%$ instead of cement 
and it is seen that the pozzolanic activity decreases depending on the increase in the ratio (Öztürk et al., 2018; Aslan et al., 2019), substitution at this ratio and below was used in this study.

When Figure 12 was examined, it was determined that the highest pozzolanic activity index in the mortar samples produced was 73\% in the ZS5 group. According to TS EN 15167-1 (2006) for the 7-day blast furnace slag to be used as pozzolan, the pozzolanic activity index must be at least 45\%, while the 7-day zinc slag mortar samples have the lowest index ZS10 test group, 8\% according to blast furnace slag standard remain safe side.

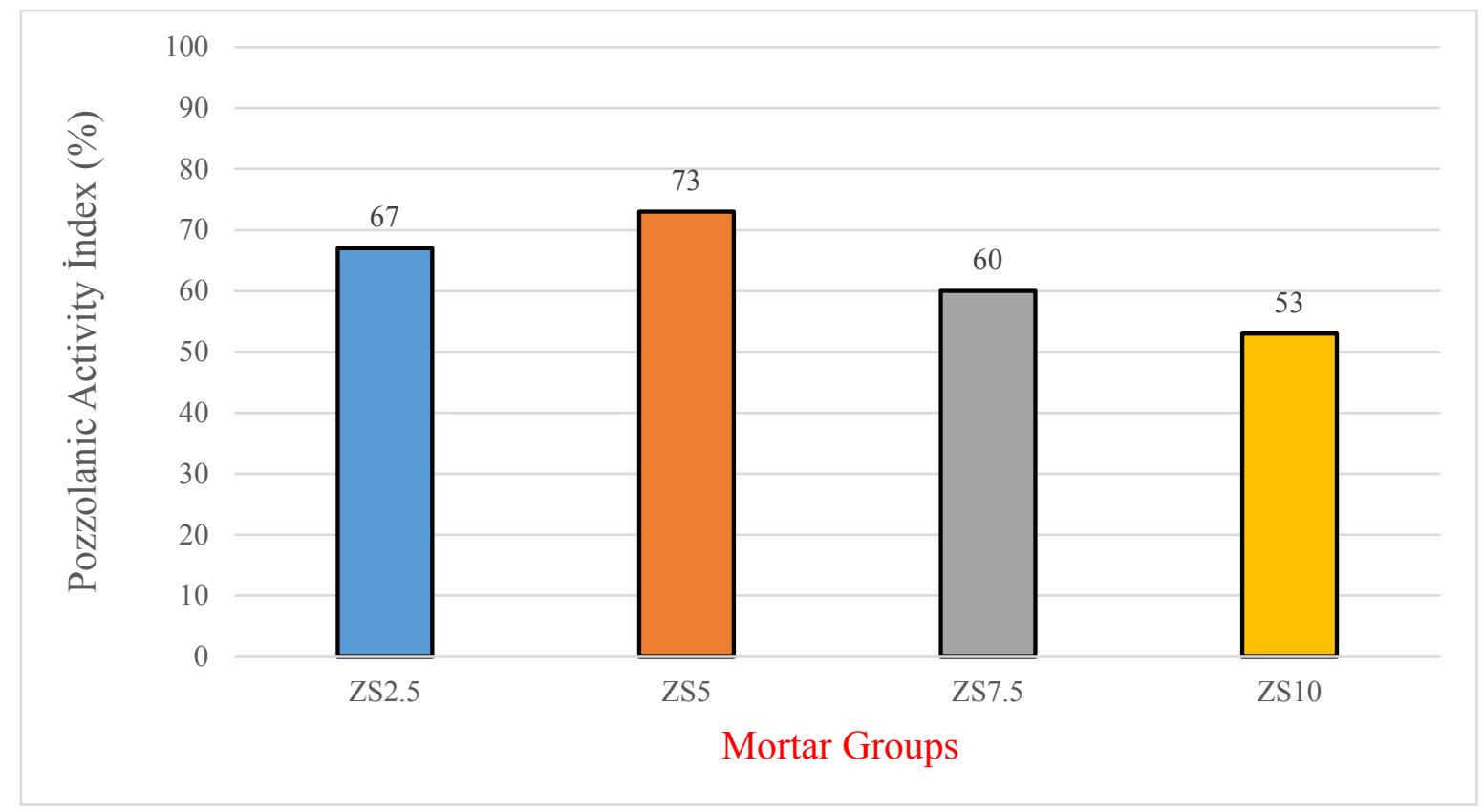

Figure 12. 7-Day pozzolanic activity index of zing slag samples.

The highest pozzolanic activity index value was seen in the ZS5 mortar group with $71 \%$ in the zinc slag mortar samples left in water curing for 28-days (Figure 13), while the optimum index value was achieved with the increase in the zinc slag replacement ratio and a decrease in the pozzolanic activity index in the mortars formed. Since the pozzolanic activity index of 28 days should be at least $70 \%$ in order for the blast furnace slag to be used as a pozzolan, the fact that the index value of the mortar group formed by using $5 \%$ of zinc slag is $71 \%$ enables this material to be used as a pozzolan. 


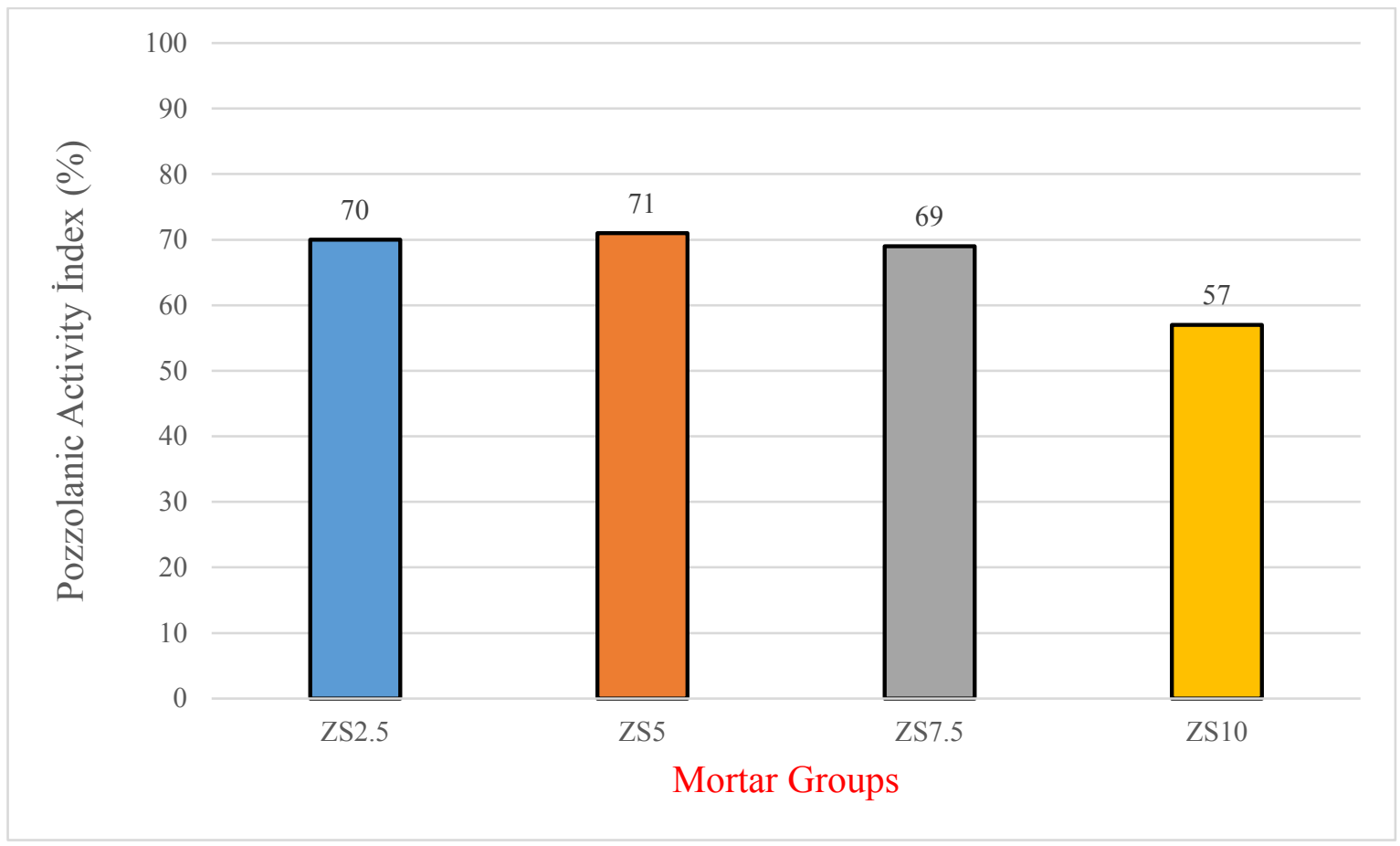

Figure 13. 28-Day pozzolanic activity index of zing slag samples.

It has been observed that the results obtained are compatible with the literature and that the obsidian material has higher pozzolanic properties due to its high silica content (Öztürk et al., 2018; Aslan et al., 2019; Kaya and Ustabaş1, 2019; Ustabaş and Ömür, 2019).

\section{Conclusions and Recommendations}

It was observed that the highest pozzolanic activity index in the obsidian mortar groups formed was $15 \%$ in both curing periods (7 and 28-days).

$\checkmark$ The highest pozzolanic activity index in the formed zinc slag mortar groups was observed to be $5 \%$ in both curing periods ( 7 and 28 -days).

$\checkmark$ It was determined that the pozzolanic activity index of the zinc slag samples was higher than the pozzolanic activity index of the obsidian samples produced by using $5 \%$ of both materials but the pozzolanic activity index of the obsidian samples was higher with a high difference in the samples created by using $10 \%$.

$\checkmark$ Thanks to the high silica ratio of obsidian, it has a positive effect on the strength by increasing it up to a certain amount in the mortar.

$\checkmark$ It has been determined that Pasinler obsidian can be used at higher rates instead of cement than zinc slag.

$\checkmark$ It has been observed that both materials can be used as pozzolan. 
Suggestions for further studies;

$>$ Determination of long-term pozzolanic activity indices (56 and 90-days) of obsidian and zinc slag,

Various mechanical tests on mortar samples produced using zinc slag and obsidian powder.

The use of both materials as pozzolan in concrete and investigation of its effect in terms of mechanics and durability.

\section{Authors' Contributions}

All authors contributed equally to the study.

\section{Statement of Conflicts of Interest}

There is no conflict of interest between the authors.

\section{References}

Akköprü, E., Mouralıs, D., Robın, A.K., Kuzucuoğlu, C., ve Erturaç, M.K., (2017). Doğu Anadolu'daki obsidiyen kaynak alanlarının belirlenmesinde jeomorfolojik ve volkanolojik göstergelerin önemi. Türkiye Jeoloji Bülteni, 60(1), 49-61.

Alameri I., Oltulu M., and Ardahanl1 M., (2020). Influence of preheating on the mechanical properties of high strength concrete with micro silica filler. Bilecik Şeyh Edebali Üniversitesi Fen Bilimleri Dergisi, 7(2): 1084-1093.

Alameri, I., Oltulu M., and Ardahanl1, M., (2019). Effect of early-age temperature on the behavior of concrete containing silica fume. 3rd International Conference on Advanced Engineering Technologies, Bayburt, Turkey.

Ardahanl1, M., Oltulu, M., and Alameri, I., (2021). Uçucu küllü kendiliğinden yerleşen betonun özellikleri üzerine ön 1sitmanın etkisi. Black Sea Journal of Engineering and Science, 4(3), 81-88.

Ardahanl1, M., Oltulu, M., and Alameri, I., (2019). Evaluation of the mechanical properties of self-compacting concrete containing fly ash subjected to early-age temperature. Hoca Ahmet Yesevi 2. Uluslararasi Bilimsel Araştırmalar Kongresi, Erzurum, Turkey.

Aslan, İ., Oltulu, M., and Karakurt C., (2019). Investigation of the waste zinc slag on the workability and mechanical properties of cement based mortars. 3rd International Conference on Advanced Engineering Technologies, Bayburt.

Bakar, D. (2005). Demir ve çelik tesislerinin yüksek demir ve karbon içeren atıklarını değerlendirme teknolojileri ve erdemir için önerilen yöntemin tanıtımı. III. Demir Çelik Kongresi ve Sergisi, Zonguldak.

Bascetin, A., Adiguzel, D., and Eker, H., (2021). Effects of puzzolanic materials in surface paste disposal by pilot-scale tests: observation of physical changes. Int. J. Environ. Sci. Technol, 18, 949-964.

Başçetin, A., Eker, H., Adigüzel, D., ve Tüylü, S., (2020). Çimentolu Macun Dolgu Yönteminin Uygulanmasında Bazı Katkı Malzemelerinin Puzolanik Özelliklerinin Araştırılması . Gümüşhane Üniversitesi Fen Bilimleri Enstitüsü Dergisi, 10(2), 415-424.

Bigazzi, G., Yeğingil, Zehra., Ercan, T., Öddöne, M., ve Özdoğan, M., (1997). Doğu Anadolu'daki obsidiyen içeren volkaniklerin "Fizyon Track" yöntemiyle yaş tayini. Türkiye Jeoloji Bülteni, 40(2), 57-72. 
Bilgin, A., Polat, S., Bilgin, N., ve Arslan, S., (2012). Erciş obsidyenlerinin mineralojik-petrografik,

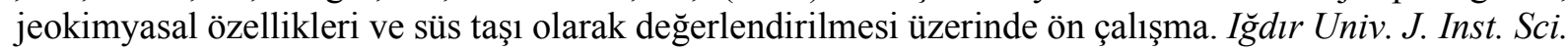
\& Tech, 2 (2), 85-92.

Ercan, T., Yeğingil, Z., Bigazzi, G., Öddöne, M., ve Özdoğan, M., (1990). Kuzeybatı anadolu obsidiyen buluntularının kaynak belirleme çalışmaları. Jeoloji Mühendisliği, 36, 19-32.

Erdoğan, S., ve Erdoğan, T., (2007). Puzolanik mineral katkılar ve tarihi geçmişleri. Yapılarda Kimyasal Katkılar Sempozyumu, Ankara.

Kaya, A., and Ustabaş, İ., (2018). Comparing the pozzolanic activity properties of obsidian to those of fly ash and blast furnace slag. Construction and Building Materials, 164, 297-307.

Moropoulou, A., Bakolas, A., and Aggelakopoulou, E., (2004). Evaluation of pozzolanic activity of natural and artificial pozzolans by thermal analysis. Thermochimica Acta, 420(1), 135-140.

Mouli, M., and Khelafi, H., (2008). Performance characteristics of lightweight aggregate concrete containing natural pozzolan. Building and Environment, 43(1), 31-36.

Nowak, A. (2014). Influence of fly ash on abrasion resistance of concretes with their additions. Key Engineering Materials, 592-593.

Öztürk, Z., Bağiran, M., Sağlar, B., Arslan, L., ve Aycan, Ş., (2018). Agrega olarak çinko madeni cürufu kullanımının beton basınç dayanımına etkisi. International Journal of Engineering Research and Development, 10 (2), 144-152.

Siddique, R. (2004). Performance characteristics of high-volume Class F fly ash concrete. Cement and Concrete Research, 34, 487-493.

Şahin, D. D., Çullu, M., ve Eker, H., (2019). Betonların Aşındırma ve Karbonatlaşma Performanslarına Kireçsi Uçucu Küllerin Farklı İncelik ve İkame Oranlarının Etkisi. Avrupa Bilim ve Teknoloji Dergisi, 17, 1150 1163.

Tohumcu İ., ve Bingöl A.F., (2013). Silis dumanı ve uçucu kül katkı1ı kendiliğinden yerleşen betonların taze beton özellikleri ve basınç dayanımları. Deü Mühendislik Fakültesi Mühendislik Bilimleri Dergisi, 15(2), 31-44.

TS EN 15167-1 (2006). Öğütülmüş yüksek firın curufu - Beton, harç ve şerbette kullanım için - Bölüm 1: Tarifler, özellikler ve uygunluk kriterleri. Türk Standartları Enstitüsü, Ankara, Turkey.

TS EN 196-2 (2013). Çimento deney yöntemleri - Bölüm 2: Çimentonun kimyasal analizi. Türk Standartları Enstitüsü, Ankara, Turkey.

TS EN 196-5 (2012). Çimento deney yöntemleri - Bölüm 5: Puzolanik çimentolarda puzolanik özellik deneyi. Türk Standartları Enstitüsü, Ankara, Turkey.

TS EN 197-1 (2012). Çimento - Bölüm 1: Genel çimentolar - Bileşim, özellikler ve uygunluk kriterleri. Türk Standartları Enstitüsü, Ankara, Turkey.

TS EN 450-1 (2013). Uçucu Kül - Betonda kullanılan - Bölüm 1: Tarif, özellikler ve uygunluk kriterleri. Türk Standartları Enstitüsü, Ankara, Turkey.

Türkiye Mühendisler ve Mimarlar Odası Birliği Jeoloji Mühendisleri Odas1, URL-1: https://www.jmo.org.tr, (Date Accessed: 15 Nisan 2021).

Ustabaş, İ., ve Ömür, İ., (2019). Rize yöresi obsidyeninin çimentonun hidratasyon 1sısına etkisi. Nevşehir Bilim ve Teknoloji Dergisi, 8(1), 78-87.

Wang, L., Zhouy, H., Shi, W., and Tang, E., (2017). Effect of silica fume and PVA fiber on the abrasion resistance and volume stability of concrete. Composites Part B: Engineering, 130, 28-37.

Wong, H.S., and Razak, H.A., (2005). Efficiency of calcined kaolin and silica fume as cement replacement material for strength performance. Cement and Concrete Research, 35, 696-702. 